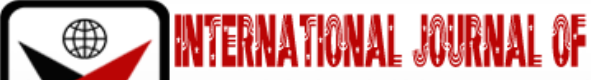

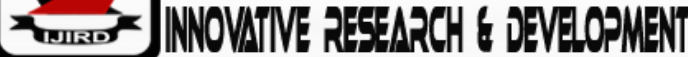

ISSN 2278-0211 (Online)

\section{Tax Planning and Capital Budgeting Decision of Listed Manufacturing Companies in Nigeria}

\begin{tabular}{c} 
Raman Adetola \\
Doctoral Student, Department of Accounting, Babcock University, Ogun State, Nigeria \\
Sunday Ajao, Owolabi \\
Professor, Department of Accounting, Babcock University, Ogun State, Nigeria \\
Ishola Rufus Akintoye \\
Professor, Department of Accounting, Babcock University, Ogun State, Nigeria \\
\hline
\end{tabular}

\begin{abstract}
:
Inadequate capital is a major factor bedeviling economic development in Nigeria and the world at large. Capital budgeting decision is sine-qua- non to the growth and expansion of business and must be premised on efficient tax planning to forestall distortionary effect on the economy. This work intends to examine the effect of tax planning on capital budgeting decision of listed companies in Nigeria. Expost-facto design was adopted and a sample of 27 companies was selected from the entire population of 54 companies using purposive and quota sampling techniques. Financial statements of selected listed companies were analyzed using multiple regression. Findings revealed that tax planning has significant positive effect on capital budgeting decision in listed manufacturing companies in Nigeria $\left(\right.$ Adj. $R^{2}=0.7734$, Wald-Stat $\left.=2620.89, p<0.05\right)$. Likewise, Financial leverage has significant moderating effect on tax planning and capital budgeting decision in listed manufacturing companies in Nigeria $\left(\right.$ Adj. $R^{2}=0.7739$, Wald-Stat $=2664.28, p<0.05)$. It was concluded that tax planning has significant effect on capital budgeting decision and financial leverage has significant moderating effect on tax planning and capital budgeting decision. The study recommended that management of listed companies should engage in lawful tax planning for better capital budgeting decision. Financial leverage should also be considered by the management of listed companies in capital budgeting decision to avoid the erosion of perceived benefit of tax planning.
\end{abstract}

Keywords: Capital budgeting, tax avoidance, tax planning, tax rate

\section{Introduction}

Globalization has affected all spheres of business activities, from technology, to raw materials, employment of labour as well as market participation. Listed companies have to take right investment decision to enable them develop and withstand the competition posed by innovations and changes among their counterparts in their operations (Avram, Avram, Ignat, Vancea, \&Horja, 2009). Basically, the prime aim of investment is to make profit that would be applied either to improve shareholders' wealth or used in enhancing future growth of an organization. This can be done by a way of fixed investment in forms of Machinery, Building and Plant \& Equipment or financial investment which includes stocks and bonds. Investments are undertaken to overcome future uncertainties. Its decision making therefore, is associated with prejudices which may boost or hamper investment performance.

Economic recession persists in Nigeria in the 2015 and 2016, the growth in GDP by 0.55\% in the second quarter of 2017 indicates emancipation from the dreadful recession. National Bureau of Statistics identified investment in manufacturing activities among others as the source of the development (The Business Year, 2018). Part of the Nigerian government efforts to promote investment decision making is the free flow of capital, enhanced through Section 24 of NIPC Act, which allows transferability of capital and returns (NIPC, 2020). Having noticed tax to GDP ratio of 6\% as one of the least in the world, the tax amnesty introduced by the federal government in June 2017 includes: voluntary declaration of 6 years taxable income by defaulters within 9 months which would absolved then from prosecutions, tax audit and the opportunity of three years' instalment payments as agreed by the tax authorities (The Business Year, 2018).

Capital inadequacy is a scourge in business development because of the need for growth in size and expansion in the span of business activities, listed companies issue both share and debt capital, firms benefit tax shield from employing debt capital, the portion of tax shield to be enjoyed depend on the thin capitalization policy in practice (Massbown, 2009). In this vein, ideal capital structure determination is a critical factor in tax planning process of listed companies in various parts of the globe (Jehan, 2001). The Nigeria Investment Promotion Commission (NIPC) granted a reduction of $60 \%$ on loan interest after the settlement of such loan in addition, $5 \%$ rebate is granted on import duty while $5 \%$ is granted on raw sugar levy imported for processing locally. Manufacturers of approved products under the scheme are granted tax holidays and $100 \%$ opportunity for exportation from the export processing zone. In addition, the federal government also 
passed the Credit Reporting Act (2017) which enable credit providers to have unhindered access to the information about their would-be borrowers, before deciding on whether or not to grant credit.

Where organizations offer to employ more of equity than debt capital, investment mobilization has become a nightmare following reluctancy of providers of fund to commit their financial resources to activities of various business organizations across the globe, the discouragement stem from wanton collapse of some companies which were inter-alia adjudged to be financially buoyant and economically bold to trade in their respective outfit (Adeniji, Akintoye\&Adegbie, 2020). In higher tax jurisdiction, cost of debt is tax deductible, hence serving as an incentive for business organizations in financing their activities greatly with debt capital. Tax planning has been adopted to lessen the effect of debt on tax revenue collection by restricting the deductible interest to a specific debt ratio culminating in international debt shifting for Multinational economies (Asuquo\&Enya, 2018). Effective domestic and foreign direct investment rely heavily on efficient tax incentive extended to existing and would be enterprises which is expected to be adequately planned to forestall distortionary effect in economic development (Mintz, 2014). One of the main determinants of investment is corporate profits which are largely influenced by the fiscal variables of average and marginal rate, investment tax credit, as well as capital allowance. Investment decision is negatively influenced by marginal as well as average tax rates (Talpos\&Vancu, 2009).

Tax planning according to Martinez and Vello, (2014) are arrays of actions undertaken by a firm to minimize tax due within the purview of ideal corporate governance which keep other costs constant without increasing its marginal effect than the tax savings. The need usually arises following impactful tax burden, experienced in tax jurisdictions, the consequence of which include reduction in tax liability, increasing cashflow, sensitizing the relevant tax authorities on the need to create tax contingencies in the future time (Hanlon \&Heitzman, 2010). Effective tax planning with good corporate governance will improve organization's returns and value (Wilson, 2009).

Tax planning, being a legal concept, has a reputational effect on tax payers and at the same time, minimizes tax liability payable without recourse to tax avoidance syndrome. It does not necessarily mean reduction in the amount of tax liability, but a deferred payment of tax liability in which the tax payer can enjoy cash flow benefit on the amount of tax deferred over a given period of time; an example of which includes rollover relief in capital gain taxation (Ftouhi\&Ghardallou, 2020). It is therefore a careful and systematic process to gain maximum benefit in line with the organization financial goal.

As identified by, Hussein, Hassan, Abdullah, Rafiq and Qudus (2020), the four important consideration of investment decision include: risk versus return; investors' risk appetite; investment incubating period as well as the availability of fund. Manufacturing companies in Nigeria are suffering from overtrading (evidenced in negative cash conversion cycle in 2019 of Champion Brewery -66 days; John Holt Nigeria PLC - 50.577days as well as Guinness Nigeria PLC of -68.9 days in 2018), inappropriate leverages (as low as 0.7\% for Cement company of Nigeria in 2019; 0.8\% in 2018; $4 \%$ for Champion Brewery in 2019, 3\% in 2018; about 9\% for Beta glass PLC in 2018), selling what customers want, sub-optimal financing (AG Leventis reduction in investment of N685,764,000 in 2019 and N17,577,025,000 in 2018; May \& Baker N58,408,000 in 2017) engaging in high cost investments with low return because of poor investment decision and finally financial distress which is capable of crippling the economic situation in a country (Memba\&Nyanumba, 2013).

Since organizations cannot get their required capital for investment from the identified sources, there is the need for them to look inward for an alternative source of income which would in actual fact involve little or no cost. This is tax savings from adequate tax planning which can be used exactly the same way as retained earnings, to finance investment decision. The role of taxation in investment and economic development of any nation cannot be over-emphasized. Frequent changes in economic climate has given way for taxation policy as a relevant tool in decision making process (Martin, 2009). Although several literatures have reviewed the significance of tax policy on investment across various countries of the world, in studies like Kasozi, (2013) investment decision was made dependent variable while the independent variables include finance, responsibility accounting, political uncertainty, risk, determinants etc., without considering how cash savings through tax planning can be used to influence capital budgeting decision. Capital budgeting decision is household name across manufacturing companies globally, however, managements and investors are oblivious of the fact that it can be influenced by their tax planning dexterity. This study therefore aims at examining the effect of tax planning on Capital budgeting decision of listed manufacturing companies in Nigeria.

\subsection{Objective of the Study}

The main objective of this study is to examine the effect of tax planning on capital budgeting decision in listed manufacturing companies in Nigeria.

The specific objective was to evaluate the moderating effect of financial leverage on the effect of tax planning on capital budgeting decision in listed manufacturing companies in Nigeria.

\subsection{Research Hypotheses}

- $\mathrm{H}_{01}$ : Tax planning has no significant effect on capital budgeting decision in listed manufacturing companies in Nigeria.

- $\mathrm{H}_{02}$ :Financial leverage have no significant moderating effect on tax planning and capital budgeting decision in listed manufacturing companies in Nigeria.

\section{Literature Review}

Capital budgeting decision is a long-term capital decision which involves accepting or rejecting some projects as a result of limited financial resources available to the organization (Anderson \& Garcia-Feijoo, 2006). It is a systematic 
process involving project identification, outcome forecast, selection of viable project, financing, implementing and monitoring the chosen project (Kumar \& Li, 2016).

According to Bierman and Smidt (2012) capital budgeting Investment decision otherwise known as fixed investment decision or long-term capital decision is the determination of the amount and the type of capital expenditure that would be employed in financing a business activity. Brealey, Myers and Allen (2011) state that it is an investment in capital or noncurrent assets of an organization that is expected to generate returns. It involves consideration of the existing capital structure of the organization in such a way that financing decision would form an integral part of the investment decision (Jehan, 2001). It entails the determination of the capital mix that would yield maximum returns. Capital budgeting decision involves decision on how cash can be exchanged for tangible assets in expectation of future profit. This decision involves the inclusion of implicit costs, that is, costs associated with marginal increase arising from changes in the organizational finance mix. A capital budgeting decision that does not consider implicit cost would result in sub-optimality.

This is investment decision made on addition, improvement or replacement of non-current assets such as Land, Equipment, Building, Plant, Collectible, Precious metals, Wine, Oil, etc. Capital budgeting decision is associated with the risk factor, when the cost of capital is higher, the return will be riskier (Stewart, 1999). It can take the form of expansion in capacity, product improvement, launching of a new product or ensuring efficient utilization of resources (Martian, 2001). Most time, it determines the effective operation of an organization and determines the cash flow for a longer time. It determines the success or otherwise of the investment and above all, it enhances organizational performance (Emmanuel, Harris \&Komakech, 2010).

Organizations need to be liquid in order to meet up short term obligations arising from various bills, as well as forestalling liquidation, at the same time, overtrading and excessive cash holding hamper effective growth, because cash would be kept idle (Jappelli\&Padula, 2011). Long-term investment decision maximizes growth opportunity on the long run. Optimum investment decision therefore entails the combination of appropriate form of long-term and short-term investment in a way that will bring fortune to the organization. Investments decision entails the choice of the commodity to invest on which include: shares, stocks, bonds, unit trust, mutual fund, real estate, spirit, gold etc. (Oteng, 2019).

Long term capital decision is determined by numerous factors which include: financial literacy, (Oteng, 2019), previous decision, sociological factor such as gender, age, cognitive biasness, product complexity and risk perception of investors (Kumar\&Li, 2016). Others include overconfidence, loss aversion and herding. It is the reason for firms' existence (Areiqat, Abu-Rumman, A-Alani, \&Alhorani, 2019).

According to Annamalah, Raman and Marthandan (2019), unit trust is an investment which can increase investors' wealth in the medium term and later in long-term. It is usually managed by experts who disperse the risk through a process called diversification. It is a low risk investment, thus bearing lower interest. Attention is shifting towards unit trust, following the high level of risks surrounding the stock market which had resulted in colossal loss that negatively affected investors across the globe (Agrrawal, Doug, \& Daniel, 2017). Notwithstanding, the rate of growth in unit trust is slow representing $0.47 \%$ annually according to the Central Bank, this indicates that the volume in unit trust is below that in the stock market (Chang et al. 2012).

Investment in tangible assets is usually undertaken to enhance perpetuity in the operation of business organizations, as well as gaining competitive edge among the peers in the market. Organization with strong financial backing prefer capital budgeting decision which can either take the form of investment on existing or new product design, research and development that will promote growth opportunity and survival in global competition (Saleh, 2018).

Capital budgeting decision centered on tangible non-current assets such as property, plant \& equipment, land, building, machinery, Real Estate which are generically referred to as real investment decision as well (Seetharaman, Niranjan, Patwa\&Kejriwal, 2017). It can be determined using payback period (PBP), which estimates the length of refund time, Net Present Value (NPV) which is the difference between the gross proceed and capital outlay, the internal rate of return (IRR) also known as the break-even rate of return, and Profitability Index (PI) which measures the ratio of NPV to initial cash outlay (Saleh, 2018; Stryckova, 2014).

Capital expenditure in the statement of financial position can be used as proxy for investment (Riem, 2016). In line with this, the study will measure Long term capital investment decision at cost less accumulated depreciation in line with International Accounting Standard (IAS) 16. Capital budgeting investment of an organization is determined by the total value of an organization assets after deducting the followings: all fictitious assets like goodwill, trademark, liabilities and preferred stock at par. That is,

Total Assets Value - (Fictitious Assets) - (Current Assets) - (Total Liabilities)

Mathematically: CBD = TAV - FA - CA - TL

It can also be stated as the summation of all tangible assets that cannot be easily convertible to cash.

Mathematically: CBD = NCA

\subsection{Theoretical Framework}

This study hinged on the theory of temporary investment tax incentive as propounded by House and Shapiro (2006). The theory emphasized the importance of tax incentives on investment decision making of various firms. Incentives are introduced to encourage investors to incur qualifying capital expenditure. Investment decision making is premised on future activities of the organization and slight delay in the acquisition of non-current assets have insignificant effect on future value of organization. The availability of tax incentive which is one of the strategies of tax planning will motivate investors to concentrate investment on qualifying assets because there will be adequate savings to encourage further investment. When there is a change in the cost of assets, incentives on such assets will bring infinitely elastic demand for investment. The theory further strengthens the significance of the savings made through efficient tax strategy as being 
very useful either to improve cash position or to motivate investment. An infinitely elastic investment supply curve will increase the quantity of investment in the short run. Tax planning activities like any other activities will initially be in the short run but the accumulated effects it has, will translate to the long run effect it will have on the investment in any company.

\subsection{Tax Planning and Capital Budgeting Decision}

Effective tax rate has been empirically determined to have negative relationship with capital budgeting investment decision (Andrejovska, 2019; Calvé, Labatut, \& Molina, 2005; Chen et al., 2010; Monterrey \& Sánchez, 2010). On the contrary, Salaudeen and Eze (2018), Richardson and Lanis (2007), Feeny, Gillman and Haris (2006) established a positive relationship while Fernández (2004) and Liu and Cao (2007) discovered existence of no relationship in the two variables. Effective Tax Rate relates significantly with the firms' value (Salawu\&Adedeji, 2017).

Suandy (2003), Ogundajo and Onakoya (2016) discovered that tax savings are conducted through the process of tax avoidance which is capable of bringing fortune to the activities of the organization through precise application of the law, reduction made in tax liability illegally is tax evasion. In the study conducted by Cao, $\mathrm{Xu}$, and Ao (2019), it is evident from previous studies that there is disproportionate effect of tax savings on investment among various countries of the world, On the basis of the economy's size. Cao, Xu, and Ao, (2019) discovered that when effective tax rate is lower, this will lead to increase in tax savings as a result of depreciation, and encourages higher investment, so also is (Shie, Ou\& Wang, 2014;Buettner, Overesch, Schreiber, \&Wamser, 2016). On the other hand, Ftouhi (2020), Shie, Ou and Wang (2014) concluded that higher tax rate will erode tax savings. The erosion is over-emphasized due to varying investment motives of MNEs in the country of operation, tax savings in form of transfer pricing and tax haven will discourage investment decision making (Ftouhi, 2020).

The tax savings effect on equity financing is significant using tax planning with book tax difference as a measure of tax savings, with the return on capital employed higher than the cost of capital which will increase investment and the value of the firm, Investors who are risk takers plan their taxes to increase savings and investment. (Cao, Xu, \&Ao, 2019; King \&Sheffrin, 2002). In the same vein, reduction in tax savings will correspondingly reduce investment by increasing rate of return and the effective after-tax capital cost, especially when anti avoidance clauses are introduced (Mgammala, \& Ismail, 2015).

Tax saving is adequate when its present value is equal to tax received on return to investment (Gordon, Kalambokidis, \&Slemrod, 2004). However, Wang, (2013); Miller \& Modigliani, (1958) agreed that tax savings through increase in debt ratio will heighten operational risk and reduce investment leading to weak capital structure because of the presence of transaction costs.

The two components of capital costs are finance and depreciation costs but, the viability depends on the addition of both (Chennels, 1996). The study conducted by Myles (2007) using Tobin Q theory revealed that capital budgeting investment decision depends on investment fair value and cost of replacement. Tax is thus a significant factor in the determination of investment decision. Long term investment decision of some firms can be motivated through various government tax policies. Fernández\&Martínez, (2011) empirically discovered that the implication of excessive tax rate in developed countries like United States is that foreign investment is encouraged while foreigners are discouraged from investing in the United States. The study concluded that reduction in corporate income tax rate will increase domestic investment.

Ahiabor and Amoah (2013) discovered a long run significant negative impact of corporate tax on fixed capital. The implication is that if investment is to be stimulated, company income tax rate would be reduced. Oloidi (2014) discovered that for both small and medium-term company, company tax is a major determinant of investment decision. Talpos and Vancu (2009) developed a model indicating that although variation in rate of tax will change the rate of investment but not its magnitude. It further posits that increase in tax rate for income derived from capital will have negative effect on the investment rate but increase in dividend tax rate will have opposite effect.

Goolsbee (1998) examined the effect of tax credit which is a form of tax savings and discovered that $10 \%$ increase in tax savings will increase the price of investment goods by about $6.5 \%$ with much of the increase absorbed in a price increase. In the same vein, Djankov, Ganser, McLiesh, Ramalho and Shleifer (2009) empirically estimate that corporation tax rate affect investment decision and other business activities significantly. Cronin, Lin, Power and Cooper (2013) estimated the portion of capital income relating to normal and supernormal return and discovered that normal return attributable to cashflow do not really impose any tax burden, the study concluded that larger portion of tax burden from corporation income tax is borne by the capital income while a low portion is attributable to labor income. In the similar vein, Heim and Lurie, (2010) through pooled data analysis determined the reactions of tax changes on both extensive and intensive margins and discovered that tax payers do not respond to after tax price changes but with a significant response to changes in profit after tax, this implies increase in tax savings associated to the changes.

Laux (2013) through regression model discovered that deferred tax predicts small degree of information about tax payable in the future, so also is (Chludek, 2011; McAnally, McGuire \& Weaver, 2010; Cheung, Krishnan, \& Min, 1997). It can also be useful in the determination of future cashflow to a firm (Cheung et al., 1997; Legoria\& Sellers, 2005). However, Foster \& Ward, (2007) argued that deferred tax does not significantly correlate with the future cashflow. RaedySeidman, and Shackleford, (2011) agreed that a deferred tax resulting from change in tax rate will significantly impact performance, capital structure and investment in a firm and also admit a relationship between book tax difference, performance and future development. While Hanlon et al. (2012) found that book tax difference determines earnings management and provide information for auditors in risk assessment of an enterprise. 
The difference in accounting and taxable income is in two ways; permanent and temporary difference. Permanent difference results from the expenses that will not be removed from the taxable profit and do not create deferred tax (Arslan, 2009 and Demir, 2009). The study conducted by Okenwa, Chinedu and Chidoziem (2017); Mear, (2011); Abedana, Omane-Antwi, and Oppong (2016) analyzed the financial statements of various companies and discovered significant statistical variations in deferred tax assets, current taxation and deferred tax liabilities but Abedana, Omane-Antwi, and Owiredu (2016) find no correlation in the extent of variation in deferred tax assets and liabilities. Deferred taxation's effect on market value and in influencing investment decision was studied by (Kim, 2015 \& Choi, 2009).

When considering the relevance of deferred tax valuation, Amir, Kirschenheiter and Willard, (1997), Badenhorst and Ferreira (2016) and Hanlon et al. (2014) discovered that deferred tax assets have positive value relevance to the market, while Samara (2014) states that deferred tax liability is negatively valued. In the same vein, the level of correlation depends on the model, structure and survey of different researchers (Ohlson\& Penman, 1992). It was also discovered that investors prefer future tax savings to negative information on loss (Amir et al., 1997; Amir \&Sougiannis, 1999). Hanna and Shaw, (2018) identified negative correlation of deferred tax asset to market value per share and investment. In the banking sector, Sözbilir, Kula and Baykut (2015) through analysis of financial statements identified right to severance settlement and financial asset valuations as the causes of deferred tax assets and liabilities respectively.

Kim, (2015), Kim and Choul (2004) examined the influence of deferred tax on market value and the effect it has on investment decision making. Costa and Pais (2015) examined the relationship between accounting for deferred taxation using IAS (International Accounting Standard) and FASB (Financial Accounting Standard Board) framework and discovered no significant difference in their application. Kyamyakova, (2014) also made a comparative study of deferred taxation and local Generally Acceptable Accounting Principle (GAAP) in Russia and also found no significant difference. In a comparative study of deferred taxation in Czech Republic and Russian Companies, a smaller standard deviation meaning was identified (Purina, 2016).

The study of Marie (2011) examined the consequence of IFRS implementation on deferred taxation assets and liabilities and concluded that the rate of increase in tax liabilities supersedes that of the tax assets. On prediction basis, future cashflow can be determined through deferred tax assets than the EU GAAP (Amaechi\&Paulinus, 2017). The deferred tax items are most often adjusted and many firms attributed changes in deferred tax to IAS changes (Newman, Edmore, Milondzo, \&Ongayi, 2016).

Permanent differences emanate from nontaxable expenses and do not result in either deferred tax or deferred liability of a firm presently and in future time (Arslan, 2009 \&Demir, 2009). Although the choice of depreciation policy is the prerogative of each companies, Ayanoglu (2001) and Sisman (2008) discovered that tax regulations determines the amount of depreciation provision through the deduction of capital allowance such that tax base of non-current assets will be higher than tax written down value (TWDV) which results in temporary difference. Another source of temporary difference as identified by Alpman (2009) is inventory value reduction with consequent declination of fair value in related assets. The study conducted by Chaney and Jeter (1989) revealed that tax payable has no significant relationship with the deferred tax. In the same vein, Cheung, Krishnan and Min (1997) through pooled time series cross sectional data conclude that deferred tax assist in the determination of tax payable. Laux (2013) investigated the relationship between reversing deferred tax and tax payable and discovered that the information provided on future tax payment is infinitesimal. However, comprehensive tax system will have a negative effect of increasing the stress of record keeping with no associated benefit. On this note, partial basis which results in lesser stress is desirable.

Tax holiday is one of the policies within the disposal of governments at various stages of development to attract investment (Nar, 2020; Tax Guide, 2018;ESCAP, 2017;World Development Report, 2004; Nathan, 2004; Altshuler, Grubert\&Newlon, 2001). Corporate organizations are making use of it (Nar, 2020), and it guarantees security of foreign currency (Muzurura\&Sikwilla, 2018). This is because it removes tax burden associated with taxable profit reported (Christians, 2009). Apart from encouraging investment, Holland and Owens (2005) identified technology transfer, employment and promotion of export as further benefit through ordinary least square method.

The World Development Report (2004) discovered that tax holidays as a form of tax avoidance rarely determine investment in tangible assets, as confirmed by the empirical studies of Harris \& Oliver, (2010) and Altshuler et al., (2001) said that tax holiday policy is a capital flight instrument used by developed countries against the developing ones. It has been found by McGee (2008) to have a detrimental economic effect on those countries that do not introduce it. Also, Blomstrom and Koko (2003) concluded that tax holiday can negatively impact on investment if it is associated with fiscal problems. In the same vein, tax holidays provided to various investors cannot be easily identified (Rosenblatt \&Terterov 2006). Lent (1967) admit that using tax holiday to drive investment in any form has not been empirically determined. Although it is easy to determine the relationship between the tax holiday and investment but, the quantum of marginal investment relating to increase in tax holiday as well as its cost effectiveness, have not been scientifically established (United Nations, 2018). Tijjani\& Peter (2020) through descriptive statistics and multiple regression discovered significant positive relationship between institutional ownership, profitability and tax planning, while ownership of cross boarder nature and firm leverage also have no negative effect. The study concluded that a relationship exists between management and institutional ownership with tax planning.

Baumann and Friehe (2010) observed that the effect of tax avoidance on capital budgeting investment are both positive and negative. Shareholders with capital budgeting decision would discourage tax avoidance because of transparency reduction and managerial opportunism (Khurana \&Mosser, 2013). Adebisi and Gbegi (2013) through analysis of variance identified that tax avoidance is positively related to the company income tax rate. Similarly, Kafkalas, Kalaitzidakis\&Tzouvelekas (2014) through artificial neutral network method discovered inverse relationship between 
gross domestic product per capital and tax avoidance. While Fatoki (2014) through a survey research design concluded that tax avoidance has negatively affected economic growth in Nigeria.

Kliestic and MikalKova, (2017) discovered empirically that tax shield as an important source of value form part of capital budgeting decision analytical tool. Glover et al (2015) empirically discovered that when tax shield is removed, it results in higher average credit spread. Tax shield affects leverage valuation as well as investment strategies (Kliestic and MikalKova, 2017).

\section{Methodology}

This study adopted expost-facto research design. The population of this study is all the 54 listed manufacturing companies in the Nigeria Stock Exchange Market as at 31 ${ }^{\text {st }}$ December, 2020. A sample of 27 companies was selected across the 5 sectors of manufacturing companies using both stratified and quota sampling techniques. The required data was obtained from the sectorial analysis of the financial statement and annual report of selected companies for the study, which covered the period of 16 years from 2004 to 2019. Panel pooled ordinary least square (OLS) method was employed in analyzing the data because, the formulated model was linear in coefficient and error terms while the error term had a population mean of zero

\subsection{Functional Relationship}

The following functional relationship were formulated for the study

$\mathrm{CBD}=f(\mathrm{ETR}, \mathrm{TA}, \mathrm{TS}, \mathrm{DT}, \mathrm{TSH}) \quad$ Equation 1

$\mathrm{CBD}=f(\mathrm{ETR}, \mathrm{TA}, \mathrm{TS}, \mathrm{DT}, \mathrm{TSH}, \mathrm{FL}) \quad$ - $\quad$ Equation 2

$\mathrm{y}_{1}=\mathrm{CBD}=$ Capital Budgeting Decision

$\mathrm{X}=\left(\mathrm{x}_{1}, \mathrm{x}_{2}, \mathrm{x}_{3}, \mathrm{x}_{4}\right.$, and $\left.\mathrm{x}_{5}\right)$

$\mathrm{x}_{1}=\mathrm{ETR}=$ Effective Tax Rate

$\mathrm{x}_{2}=\mathrm{TA}=\mathrm{Tax}$ Avoidance

$\mathrm{x}_{3}=\mathrm{TS}=$ Tax Savings

$\mathrm{x}_{4}=\mathrm{DT}=$ Deferred Taxation

$\mathrm{x}_{5}=\mathrm{TSH}=\mathrm{Tax}$ Shield

$\mathrm{Z}=\mathrm{z}_{1}$,

$\mathrm{Z}_{1}=\mathrm{FL}=$ Financial Leverage

Model Specification

CBDit $=\beta_{0}+\beta_{1} \mathrm{ETR}_{\mathrm{it}}+\beta_{2} \mathrm{TA}_{\mathrm{it}}+\beta_{3} \mathrm{TS}_{\mathrm{it}}+\beta_{4} \mathrm{DT}_{\mathrm{it}}+\beta_{5} \mathrm{TSH}_{\mathrm{it}}+\mu_{\mathrm{it}} \quad \ldots \ldots \ldots \ldots . .$. Model 1

CBDit $=\beta_{0}+\beta_{1} \mathrm{ETR}_{\mathrm{it}}+\beta_{2} \mathrm{TA}_{\mathrm{it}}+\beta_{3} \mathrm{TS}_{\mathrm{it}}+\beta_{4} \mathrm{DT}_{\mathrm{it}}+\beta_{5} \mathrm{TSH}_{\mathrm{it}}+\beta_{6} \mathrm{FL}_{\mathrm{it}}+\mu_{\mathrm{it}} \quad \ldots \ldots \ldots \ldots$..... Model 2

\section{Results and Discussion of Findings}

\subsection{Test of Hypotheses}

\subsubsection{Hypothesis One}

4.1.1.1. Research Objective 1

Examine the effect of tax planning on capital budgeting decision in listed manufacturing companies in Nigeria.

\subsubsection{Research Question 1}

How does tax planning affect capital budgeting decision in listed manufacturing companies in Nigeria?

\subsubsection{Research Hypothesis 1}

Tax planning has no significant effect on capital budgeting decision in listed manufacturing companies in Nigeria.

\subsubsection{Hypothesis Two}

\subsubsection{Research Objective 2}

Evaluate the moderating effect of financial leverage on the effect of tax planning on capital budgeting decision in listed manufacturing companies in Nigeria.

\subsubsection{Research Question 2}

In what way does financial leverage moderate the effect of tax planning on capital budgeting decision in listed manufacturing companies in Nigeria?

\subsubsection{Research Hypothesis 2}

Financial leverage has no significant moderating effect on tax planning and capital budgeting decision in listed manufacturing companies in Nigeria. 


\begin{tabular}{|c|c|c|c|c|c|c|c|c|}
\hline & \multicolumn{4}{|c|}{ Model One } & \multicolumn{4}{|c|}{$\begin{array}{c}\text { Model Two (Inclusive of Moderating } \\
\text { Variable) }\end{array}$} \\
\hline & \multicolumn{4}{|c|}{$\begin{array}{c}\text { 'Prais-Winstenregression, correlated } \\
\text { panels corrected standard errors } \\
\text { (PCSEs)' }\end{array}$} & \multicolumn{4}{|c|}{$\begin{array}{l}\text { 'Prais-Winsten regression, correlated panels } \\
\text { corrected standard errors (PCSEs)' }\end{array}$} \\
\hline Variable & Coeff. & SE & t-test & Prob. & Coeff. & SE & t-test & Prob. \\
\hline Constant & .3863 & .0969 & 3.99 & 0.000 & .3904 & .09590 & 4.07 & 0.000 \\
\hline ETR & .0011 & .0008 & 1.34 & 0.181 & .00109 & .00080 & 1.37 & 0.171 \\
\hline TA & -.0016 & .0020 & -0.77 & 0.444 & -0.0016 & .0020 & -0.79 & 0.4320 \\
\hline TS & .3802 & .0501 & 7.59 & 0.000 & .3790 & .04997 & 7.59 & 0.000 \\
\hline DT & .0098 & 0.032 & 3.02 & 0.003 & .099 & .0326 & 3.03 & 0.0021 \\
\hline TSH & .4353 & .0358 & 12.17 & 0.000 & .4366 & .03541 & 12.33 & 0.000 \\
\hline FL & - & - & - & - & -.0102 & .0086 & -1.19 & 0.234 \\
\hline Adj. R²; Prob.(F-Stat) & \multicolumn{4}{|c|}{$0.7734 ; 0.0000$} & \multicolumn{4}{|c|}{$0.687 ; 0.0000$} \\
\hline Diagnostics Test & \multicolumn{2}{|c|}{ Statistics } & \multicolumn{2}{|c|}{ Prob. } & \multicolumn{2}{|l|}{ Statistics } & \multicolumn{2}{|l|}{ Prob. } \\
\hline Wald-Stat & \multicolumn{2}{|c|}{2620.89} & \multicolumn{2}{|c|}{0.0000} & \multicolumn{2}{|l|}{2664.28} & \multicolumn{2}{|l|}{0.0000} \\
\hline Hausman Test & \multicolumn{2}{|c|}{32.65} & \multicolumn{2}{|c|}{0.0002} & \multicolumn{2}{|l|}{-32.18} & \multicolumn{2}{|l|}{0.0001} \\
\hline $\begin{array}{c}\text { Breusch-Pagan LM } \\
\text { test } \\
\end{array}$ & \multicolumn{2}{|c|}{34.51} & \multicolumn{2}{|c|}{0.0000} & \multicolumn{2}{|l|}{26.05} & \multicolumn{2}{|l|}{0.0000} \\
\hline $\begin{array}{l}\text { Heteroskedasticity } \\
\text { Test }\end{array}$ & \multicolumn{2}{|c|}{96.7} & \multicolumn{2}{|c|}{0.0000} & \multicolumn{2}{|l|}{97.55} & \multicolumn{2}{|l|}{0.0209} \\
\hline Pesaran's Test of CSID & \multicolumn{2}{|c|}{2.045775} & \multicolumn{2}{|c|}{0.048} & \multirow{2}{*}{$\begin{array}{c}5.0303 \\
1.48872 \\
\end{array}$} & \\
\hline Durbin-Watson d-stat & \multicolumn{2}{|c|}{1.49623} & & & & & & \\
\hline
\end{tabular}

Table 1: Test of Hypothesis One and Hypothesis Two

Source: Researcher's Computation (2021)

Notes:Table 1 reports 'Prais-Winsten regression, correlated panels corrected standard errors (PCSEs)' results of the effect of tax planning on capital budgeting decision. The dependent variable is capital budgeting decision. The independent variables are: effective tax rate (ETR), tax avoidance (TA), tax savings (TS), deferred taxation (DT) and tax shield (TSH). The moderating variable is financial Leverage (FL).

\subsection{Interpretation}

In determining the most suitable model for estimating the regression model 1 , Hausman test was conducted, from the result as indicated in Table 1 above, Prais-Winsten regression, correlated panels corrected standard errors (PCSEs) was found to be most appropriate estimator based on the presence of heteroskedasticity with the $p$-value of 0.0000 and autocorrelation result with Durbin-Watson statistic value $(1.49623<2)$ indicating the presence of autocorrelation. However, before choosing Prais-Winsten regression, correlated panels corrected standard errors (PCSEs) as the most appropriate, the fixed effect was the selected estimator based on the $p$-value of Hausman test. Wald-Stat was conducted to confirm the outcome of the Hausman test. The presence of heteroskedasticity and autocorrelation with the fixed effect model as chosen shows that there is need to regress for Prais-Winsten regression, correlated panels corrected standard errors (PCSEs) as assumed by fixed effect, since the number of firms ( $\mathrm{n}$ ) is more than the number of years ( $\mathrm{t}$ ) ( $\mathrm{n}>\mathrm{t}$ ). The null hypothesis of the Hausman specification test is that there is no correlation between the random effects and fixed effect model, thus the random effect estimates are efficient and consistent, and that the fixed effect estimates are inefficient. The Hausman test result was $p$-value $=0.0002$, which is below the $5 \%$ level of significance, meaning the rejection of the null hypothesis. The Wald-Stat test was conducted to confirm the authenticity of Hausman result, and the result of Wald-Stat indicates $p$-value $=0.0000(p<0.05)$, which supports the Hausman test. However, the heteroskedasticity test revealed a significant $p$-value $=0.0000$ which indicates the presence of heteroskedasticity. Therefore, Prais-Winsten regression, correlated panels corrected standard errors was found to be the most appropriate estimator for the model because the number of firms in the panel is more than the number of years.

In the same vein, when the financial leverage (FL) was introduced as control variables, Hausman test result was also in favor of fixed effect with a $p$-value $=0.0001(p<0.05)$ lower than $5 \%$ chosen level of significance. The heteroscedasticity test with $p$ value $0.0209<0.05$ and Durbin-Watson d statistic of $1.48872<2$ indicate the presence of heteroscedasticity and autocorrelation respectively.Therefore, Prais-Winsten regression, correlated panels corrected standard errors (PCSEs) was considered the most appropriate estimator.

\subsection{Diagnostic Tests}

Heteroskedasticity, autocorrelation and cross-sectional dependence tests were conducted on the models to determine their robustness. Durbin-Watson d static was employed for autocorrelation, the interpretation of the test is that $\mathrm{DW}=2$, no autocorrelation, $\mathrm{DW}<2$ means positive autocorrelation while $\mathrm{DW}>2$ implies negative autocorrelation. The dstatistic $(6,402)=1.49623$ means that auto correlation (first order) exists among the companies sampled for the study. For the test, the null hypothesis states that there is no correlation in the residuals of the models over time. The heteroscedasticity test was conducted through the White test for heteroscedasticity, with homoscedastic being the null hypothesis of the test and the results gave $p$-values $=0.0000 ; p=0.0209$ for both models one and two, respectively. The 
implication of these is that there is no presence of homoscedasticity in both models one and two. These imply that the residuals of both models are static and their standard errors are correlated over time. For the appropriateness of both models, fixed effect from the hausman test in relation to the presence of heteroskedasticity indicates the need to use 'Prais-Winsten regression, correlated panels corrected standard errors (PCSEs)' to estimate the models. This is because fixed effect assumes that when heteroskedasticity is present, Prais-Winsten regression, correlated panels corrected standard errors (PCSEs) should be used when the number of firms is greater than number of years.

To determine the cross-sectional dependence between the selected listed companies of the study, the Pesaran CSID test was used. The statistic of 2.045 with a probability value of 0.0408 and 5.0303 with probability value of 0.0000 for models one and two respectively are statistically significant at 5\% level of significance. This implies that the selected listed companies are cross sectional dependence.

\subsection{Without Moderating Variable (Model One)}

The results of the post-estimation tests carried out estimated model one using Prais-Winsten regression, correlated panels corrected standard errors (PCSEs) as shown in Table 1.

CBDit $=\beta_{0}+\beta_{1} \mathrm{ETR}_{\mathrm{it}}+\beta_{2} \mathrm{TA}_{\mathrm{it}}+\beta_{3} \mathrm{TS}_{\mathrm{it}}+\beta_{4} \mathrm{DT}_{\mathrm{it}}+\beta_{5} \mathrm{TSH}_{\mathrm{it}}+\mu_{\mathrm{it}} \quad \ldots \ldots \ldots \ldots$..... Model 1

$\mathrm{CBDit}=0.3863+0.0011 \mathrm{ETR}_{\mathrm{it}}-0.0016 \mathrm{TA}_{\mathrm{it}}+0.3802 \mathrm{TS}_{\mathrm{it}}+0.0098 \mathrm{DT}_{\mathrm{it}}+0.4353 \mathrm{TSH}_{\mathrm{it}}+\mu_{\mathrm{it}}$

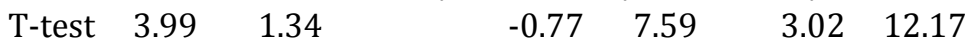

Table 1 shows the results of regression analysis of the effects of tax planning on capital budgeting decision in listed manufacturing companies in Nigeria. The results show that tax effective tax rate, tax savings, deferred taxation and tax shield have positive relationship with capital budgeting decision of listed manufacturing companies in Nigeria, while tax avoidance is negatively related.

In addition, there is evidence that tax savings, deferred tax and tax shield have significant relationship with capital budgeting decision of listed manufacturing companies in Nigeria $(\mathrm{TS}=0.3802$, t-test $=7.59, p<0.05, \mathrm{DT}=0.0098, \mathrm{t}$-test $=$ 3.02 , with $p$-value less than 0.05 , TSH $=0.4353$, t-test $=12.17, p$-value below 0.05$)$. The inference from this is that tax savings, deferred taxation and tax shield are significant factors influencing changes in the capital budgeting decisions of listed manufacturing companies in Nigeria.

On the contrary, effective tax rate and tax avoidance do not have significant relationship with the capital budgeting decision of listed manufacturing companies in Nigeria (ETR $=0.0011$, t-test $=1.34, p>0.05, \mathrm{TA}=-0.0016, \mathrm{t}$-test $=-0.77, p>$ 0.05). This means that effective tax rate and tax avoidance are not significant factor influencing changes in the capital budgeting decisions of listed manufacturing companies in Nigeria.

For the magnitude of the parameters estimated, using the coefficients of the regression analysis, a unit increase in effective tax rate and tax avoidance will lead to $0.11 \%$ increase and $0.16 \%$ decrease in the capital budgeting decision of listed manufacturing companies in Nigeria respectively, while one percent increase in tax savings, deferred taxation and tax shield will lead to $0.38 \%, 0.098 \%$ and $0.4 \%$ increase in capital budgeting decision of listed manufacturing companies in Nigeria respectively.

In the study, F-statistics was employed to determine the overall significance of the independent variables on the dependent variable as well as in ascertaining whether all the coefficients of independent variables determined are not zero (0). From the Table 1 , model 1 gives $p$-value of $\mathrm{F}$ - statistics equals 0.0000 , and it is significant at $5 \%$. This confirms that the explanatory variables (ETR, TA, DT, TS and TSH) are linearly related to the dependent variable (CBD). The Adjusted R ${ }^{2}$ which measure the proportion of changes in the capital budgeting decision of listed manufacturing companies in Nigeria as a result of changes in effective tax rate, tax avoidance, tax savings, deferred taxation and tax shield account for approximately $77.3 \%$ variation in the capital budgeting decision of listed manufacturing companies in Nigeria, other factors not captured in the model explained the remaining $22.7 \%$ of the changes in the capital budgeting decision of listed manufacturing companies in Nigeria.

\subsection{Decision Rule}

The Wald-Test of 2620.89 is statistically significant with $p<0.05$. At the level of significance 0.05 , The Wald-Test recorded 2620.89 while the probability of the Wald-Test is 0.0000 which is less than 0.05 adopted level of significance indicating that on the overall, the statistical significance of the model showed that the null hypothesis of tax planning has no significant effect on capital budgeting decision in listed manufacturing companies in Nigeriawas rejected. Thus, the alternative hypothesis that tax planning has significant effect on capital budgeting decision in listed manufacturing companies in Nigeriawas accepted.

\subsection{Model Two Inclusive of Moderating Variable}

The post-estimation tests conducted recommended through its result that model two should be estimated using 'Prais-Winsten regression, correlated panels corrected standard errors (PCSEs)'as shown in Table 1.

CBDit $=\beta_{0}+\beta_{1} \mathrm{ETR}_{\mathrm{it}}+\beta_{2} \mathrm{TA}_{\mathrm{it}}+\beta_{3} \mathrm{TS}_{\mathrm{it}}+\beta_{4} \mathrm{DT}_{\mathrm{it}}+\beta_{5} \mathrm{TSH}_{\mathrm{it}}+\beta_{5} \mathrm{FL}_{\mathrm{it}}+\mu_{\mathrm{it}} \ldots \ldots \ldots$... Model 4

CBDit $=0.3904+0.0011 \mathrm{ETR}_{\mathrm{it}}-0.0016 \mathrm{TA}_{\mathrm{it}}+0.379 \mathrm{TS}_{\mathrm{it}}+0.099 \mathrm{DT}_{\mathrm{it}}+0.4366 \mathrm{TSH}_{\mathrm{it}}-0.076 \mathrm{FL}_{\mathrm{it}}+\mu_{\mathrm{it}}$

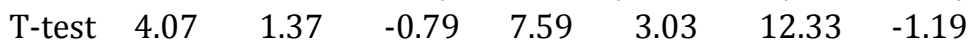

The introduction of financial leverage (FL) as control variable to model 1 to form model 2 results show that effective tax rate, tax savings, deferred taxation and tax shield have positive relationship while tax avoidance and the control variable introduced on the other hand has a negative relationship with capital budgeting decision of listed manufacturing companies in Nigeria. 
Also, the result indicates that tax savings, deferred tax and tax shield have significant relationship with capital budgeting decision of listed manufacturing companies in Nigeria $(\mathrm{TS}=0.3790$, $\mathrm{t}$-test $=7.59, p<0.05, \mathrm{DT}=0.099$, $\mathrm{t}$-test $=3.03$, $p<0.05, \mathrm{TSH}=0.4366$, t-test $=12.33, p$-value $<0.05$ ). It means that tax savings, deferred taxation and tax shield are significant factors influencing changes in the capital budgeting decisions of listed manufacturing companies in Nigeria.

On the contrary, effective tax rate, tax avoidance and financial leverage do not have significant relationship with the capital budgeting decision of listed manufacturing companies in Nigeria $(\mathrm{ETR}=0.00109, \mathrm{t}$-test $=4.07, p$-value $>0.05, \mathrm{TA}=-$ 0.0016 , t-test $=-0.79, p$ value $>0.05, \mathrm{FL}=-0.0102$, $\mathrm{t}$-test $=-1.19, p$-value $>0.05$ ). It means effective tax rate, tax avoidance and financial leverage are not significant factors influencing changes in the capital budgeting decisions of listed manufacturing companies in Nigeria.

Considering the magnitude of the estimated parameters for the coefficients of the regression analysis, a unit increase in effective tax rate, and unit decrease in tax avoidance will lead to $1 \%$ and $0.16 \%$ increase in the capital budgeting decision of listed manufacturing companies in Nigeria respectively, but a unit increase in financial leverage will result in a reduction in the capital budgeting decision of listed manufacturing industries in Nigeria by $1.02 \%$. Also, one percent increase in tax savings, deferred taxation and tax shield will lead to $0.379 \%, 0.099 \%$ and $0.4366 \%$ increase in capital budgeting decision of listed manufacturing companies in Nigeria respectively.

F-statistics probability was employed in assessing the significance of the explanatory variables in its entirety on the dependent variable and to examine that the obtained values of the independent variables are not zero (0).

Table 1 above also indicates that, the Probability of $F$-Stat for model 4 is 0.0000 , and it is significant at 5 percent. This confirms that the explanatory variables (ETR, TA, DT, TS, TSH and FL) are directly related to Capital budgeting decision (CBD). The Adjusted $\mathrm{R}^{2}$ which measure the proportion of changes in the capital budgeting decision of listed manufacturing companies in Nigeria as a result of changes in effective tax rate, tax avoidance, tax savings, deferred taxation, tax shield and financial leverage account for $77.39 \%$ of the changes in the capital budgeting decision of listed manufacturing companies in Nigeria, the remaining $22.61 \%$ were as a result of other factors explaining variations in the capital budgeting decision of listed manufacturing companies in Nigeria, which were not captured in the model.

\subsection{Decision Rule}

The Wald-Test of 2664.28 is statistically significant with $p<0.05$.At the level of significance 0.05 , The Wald-Test recorded 2664.28 while the probability of the Wald-Test is 0.0000 which is less than 0.05 adopted level of level of significance indicating that on the overall, the statistical significance of the model showed that the null hypothesis of Financial leverage has no significant control on tax planning and capital budgeting decision in listed manufacturing companies in Nigeria was rejected. Thus, the alternative hypothesis that financial leverage has significant moderating effect on the relationship between tax planning and capital budgeting decision in listed manufacturing companies in Nigeria was accepted.

\section{Discussion of Findings}

This study examines the effect of tax planning on investment decision of listed manufacturing companies in Nigeria. In line with the objective, this section discusses the findings of the effect of tax planning on capital budgeting decision of listed manufacturing companies in Nigeria. Tax planning as an explanatory variable was proxied with effective tax rate, tax avoidance, deferred taxation, tax savings as well as the tax shield. The empirical findings of the study through Prob (FStatistics) confirmsthattax planning has significant effect on capital budgeting decision of listed manufacturing companies in Nigeria. It implies that the sampled firms determine the extent of their investment in noncurrent assets with recourse to each or aggregate tax planning strategies of effective tax rate, tax avoidance, deferred taxation, tax savings and tax shield.

Capital budgeting decision making being influenced by tax planning strategies is as a result of the fact that capital allowance is claimable from the acquisition of non-current assets provided the assets are acquired in a particular year of assessment, put into use in the same year, without disputing ownership and the assets are used till the end of the year of assessment (Bruhne\& Jacob, 2019). There is also tax planning in assets disposal. The capital gain tax on disposal of the qualifying capital expenditure can be minimized through partial or full rollover relief. The positive relationship exhibited between tax planning proxies and capital budgeting decision is as a result of the fact that effective tax planning would occasioned increase in investible capital, the more tax is planned, the more the availability of fund to be divested into capital budgeting decision which will invariably lead to increase in asset based and consequently better organizational performance. This is further explained by Cao, Xu, and Ao, (2019) that when tax liability is lower, it will lead to increase in tax savings as a result of depreciation, and encourages higher investment, so also is (Shie, Ou\& Wang, 2014;Buettner, Overesch, Schreiber, \&Wamser, 2006).

The tax planning strategy that exhibit highest influence on capital budgeting decision is the tax shield. This is because capital budgeting can be financed through either debt or equity capital or combination of both. When debt capital is involved, the interest element is a deductible item and the tax portion of the interest allowed becomes the tax shield. The tax planning advantage on debt financing can motivate listed firms to involve in capital budgeting investment decision. As a result of this, tax planning is one of the determinants of capital budgeting investment decision.

The Adjusted R-Squares (77.3 and 77.39) with $p<0.05$ indicate significant and higher influence of tax planning on capital budgeting decision of listed manufacturing companies in Nigeria. The result is the same with the empirical result of $\mathrm{Cao}, \mathrm{Xu}$, and Ao, (2019) that tax savings has a significant effect on equity, when return on capital is higher than the cost of capital, there will be increase in investment. The findings are also in line with the empirical results of Salaudeen and Eze (2018), that there is a positive relationship between tax planning and capital budgeting investment decision. This is also supported with the view of Salawu and Adedeji (2017) that effective tax rate has a significant relationship with the firms' 
value. It is also in consonance with the empirical result of Kliestic and MikalKova, (2017) that tax shield affects leverage valuation as well as investment strategies.

The results also corroborate the findings of Mgammala and Ismail (2015) that reduction in tax savings will reduce investment by increasing the effective tax rate and the cost of capital. The findings also confirm the empirical results of Talpos and Vancu (2009) that although a change in tax rate will affect the rate of investment but not its magnitude. The study also confirmed the result of Harris \& Oliver, (2010) that tax avoidance determine investment in tangible assets. It is also in line with the view of Baumann and Friehe (2010) that tax avoidance has positive and negative effect on capital budgeting investment.

The result confirms the a priori expectation of positive relationship between tax planning and capital budgeting decision and negates that of financial leverage. The empirical results are also in line with the theory of investment tax incentives because, the theory states that investment decision has a feed forward effect on organization's activities which means that acquisition of item of qualifying capital expenditure is determined by future activities of the business. However, the findings negate the empirical findings of Andrejovska, (2019) and Chen et al (2010) that effective tax rate has negative relationship with capital budgeting investment decision. It is also not consistent with the findings of Cao, $\mathrm{Xu}$, and Ao, (2019) that decrease in effective tax rate will increase tax savings and investment. The result is also contrary to the view of Wang, et al (2020) that tax savings increase operational risk and reduce investment, thus resulting in weak capital structure. it also negates the empirical findings of Ward and Price (2006) and Chashandani and Martani (2012) that positive relationship exists between tax planning and financial leverage.

\section{Conclusion and Recommendation}

The study empirically investigated the effect of tax planning on capital budgeting investment decision of listed manufacturing industries in Nigeria. Based on the findings stated above, the study concluded as follows, tax planning has significant effect on capital budgeting decision of listed manufacturing companies in Nigeria. Financial leverage has significant moderating effect on tax planning and capital budgeting decision of listed manufacturing companies in Nigeria.

The study recommends as follows:

Tax savings, deferred tax and tax shield are significant factors determining the capital budgeting decision of listed manufacturing companies, therefore management should engage in lawful tax planning to have a better capital budgeting decision.

In order to enjoy adequate tax planning and capital budgeting decision in listed manufacturing companies, adequate consideration should be given to leverage by the managements of listed manufacturing companies since poor combination of Debt Vs Equity can erode the perceived benefit of tax planning.

\section{References}

i. Abedana, V. N., Omane-Antwi, K. B., \&Owiredu, A. (2016). The impact of IFRS/IAS adoption on corporate income taxation in Ghana. International Journal of Accounting and Financial Reporting, 6(1), 72-95.

ii. Adebisi, F. A. and Gbegi, D. O. (2013). Effect of tax avoidance and tax evasion on personal income tax administration in Nigeria. American Journal of Humanities and Social Sciences, 1(3), 125-134.

iii. Adeniji, Y. A., Akintoye, I. R.., \&Adegbie, F. F. (2020). Responsibility accounting and corporate investment decisions among listed manufacturing firms in Nigeria. European Journal of Accounting, Auditing and Finance Research, 8(4), 89-111.

iv. Agrrawal, P., Doug W., \& Daniel, H. S. (2017). Suicides as a response to adverse market sentiment (1980-2016). PLoS ONE 12: e0186913. doi: 10.1371/journal.pone.0186913.

v. Ahiator, G., \&Amoah, A. (2013). The effects of corporate taxes on the level of investment in Ghana. Development Country Studies, 3(1), 57-67.

vi. Alpman, D. (2009). Uluslararasıfinansalraporlamastandartlarınagenelbirbakışvebiruygulama Accessed, 25 October, 2020.

vii. Altshuler, R., Grubert, H., \&Newlon, S. (2001). Has U.S. investment abroad become more sensitive to tax rates? In J. $R$. Hines (Ed.), International Taxation and Multinational Activity. The University of Chicago Press.

viii. Amaechi, E. P., \&Paulinus, O. O. (2017). Tax Implication of International Accounting Standards (IAS 12) Adoption: Evidence from Deposit Money Banks (DMBS) in Nigeria. International Journal of Social and Administrative Sciences, 2(2), 52-62. https://doi.org/10.18488/journal.136.2017.22.52.62

ix. Amir, E., \&Sougiannis, T. (1999). Analysts 'interpretation and investors 'valuation of tax carryforwards. Contemporary Accounting Research, 16(1), 1-34.

x. Annamalah, S., Raman, M., Marthandan, G. \&Logeswaran, A.K. (2019). An empirical study on the determinants of an investor's decision in unit trust investment. Economies, 1-23.

xi. Anderson, C. H., \& Garcia-Feijoo, L. (2006). Empirical evidence on capital investment, growth options and security returns. The journal of Finance, 61(1), 171-194.

xii. Andrejovska, A. (2019). Effective tax rate in the content of economic determinants. Montenegrin Journal of Economics, 15(2), 31-40.

xiii. Areiqat, Y. A., Abu-Rumman, A., A-Alani, Y. S., \&Alhorani, A. (2019). Impact of behavioral finance on stock investment decisions: Applied study on a sample of investors at Amman Stock Exchange. Academy of Accounting and Financial Studies Journal, 23(2).

xiv. Arslan, E. (2009). TMS-12 gelirvergilerininmuhasebeleştirilmesistandardı, ankara: Maliyevehukukyayınları. 
xv. Asuquo, A. I., \&Enya, E. F. (2018). Effects of thin capitalization and international law on performance of multinational companies in Nigeria. Journal of Accounting and Financial Management, 4(2), 47-59.

xvi. Avram, L. S., Avram, C., Ignat, A. S., Vancea, S., \&Horja, M. I. (2009). Investment decision and its appraisal. DAAAM International, Vienna, Austria, EU, 20(1), 1905-1906.

xvii. Brealey, R. A., Myers, S. C., \& Allen, F. (2011). Principles of Corporate Finance (10th ed). ew York: McGraw-Hill.

xviii. Bierman, H. J., \&Smidt, S. (2012). The capital budgeting decision. Economic analysis of investment projects (9th ed). Routledge: Taylor \& Francis Group.

xix. Blomstrom, M., \&Kokko, A. (2003). The Economics of foreign direct investment incentives. (Unpublished work paper) $w w w . E F D / / .10 / / /$ Economics (2003).

xx. Bruhne, A., \& Jacob, M. (2019). Corporate tax avoidance and the real effects of taxation: A review. Working paper, WHU-Otto Beisheim School of Management.

xxi. Buettner, T., Overesch, M., Schreiber, U., \&Wamser, G. (2016). The impact of thin capitalization rules on the capital structure of multinational firms. $\quad$ Retrieved from https://www.sciencedirect.com/science/article/abs/pii/S0047272712000710.

xxii. Calvé Pérez, J., Labatut, S., G. \& Molina L. R. (2005). Variables económico-financierasqueincidensobre la presión fiscal Martínez y Álvarez, soportadaporlasempresas de reducidadimensión: efectos de la reforma fiscal de 1995 en lasempresas de la ComunidadValenciana. Revista Española de Financiación y Contabilidad, 127, 875-897.

xxiii. Cao, H., Xu, X., \&Ao, G. (2019). Study on the tax planning of enterprise income tax. International Journal of Business and Management, 4(5).

xxiv. Chaney, P. K., \& Jeter, D. C. (1989). Accounting for deferred income taxes: Simplicity? Usefulnes. Accounting Horizons. 3(2), 6-13.

xxv. Chang, C. E., Walt, A. N., \& Witte, H. D. (2012). Do green mutual funds perform well? Management Research Review, 35, 693-708. doi:10.1108/01409171211247695.

xxvi. Chen, S., Chen, X., Cheng, T. \&Shevlin, T.J. (2010). Are family firms more tax aggressive than non-family firms? Journal of Financial Economics, 95, 41-61.

xxvii. Chennels, L. (1996). Taxation, corporation in M. Warner (Ed) International Encyclopedia of Business and Management, 5(6), 4768-4781.

xxviii. Cheung, J. K., Krishnan, G. V., \& Min, C. (1997). Does inter-period income tax allocation enhance prediction of cash flows? Accounting Horizons, 11(4), 1-15.

xxix. Chludek, A. K. (2011). Perceived versus actual cash flow implications of deferred taxes - An analysis of value relevance and reversal under IFRS. Journal of International Accounting Research, 10(1), 1-25.

xxx. Cheung, J. K., Krishnan, G. V., \& Min, C. (1997). Does inter-period income tax allocation enhance prediction of cash flows? Accounting Horizons, 11(4), 1-15.

xxxi. Christians, A. (2009). Tax treaties for investment and aid to Sub-Saharan Africa: A Case study. in K. P. Sauvant, \& L. E. Sachs (Eds.), The Effect of Treaties on Foreign Direct Investment: Oxford University Press.

xxxii. Costa, P.A., \&Pais, C.A. (2015). The accounting of deferred tax assets in the USA and Europe and its effects on the investors. Tourism and Management Studies, 11, $204-210$.

xxxiii. Cronin, J. A., Lin, E. Y., Power, L., \& Cooper, M. (2013). Distributing the corporate income tax: Revised U.S. Treasury methodology. National Tax Journal, 66(1), 239-262.

xxxiv. Djankov S., Ganser, T., McLiesh, C., Ramalho, R., \&Shleifer, A. (2009). The effect of corporate taxes on investment and entrepreneurship. NBER Working Paper 13756, Cambridge, Massachusetts.

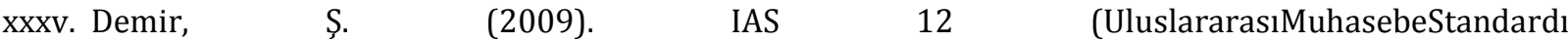
http://www.tmsk.org.tr/makaleler/tms\%2012/IAS\%2012\%20(ULUSLARARASI\%20MUHASEBE\%20STAND ARDI\%2012).doc.

xxxvi. Emmanuel, C., Harris, E., \&Komakech, S. (2010). Towards a better understanding of capital investment decisions. Journal of Accounting and Organizational Change, 6(4), 477-504.

xxxvii. ESCAP. (2017). Tax incentives and tax base protection in developing countries. www.unescap.org for further information.

xxxviii. Fatoki, J. O. (2014). An Empirical study of tax evasion and tax avoidance: A critical issue in Nigeria economic development. Journal of Accounting and Organizational Change, 6(4), 37-50.

xxxix. Feeny, S., Gillmann, M. \& Harris, M.N. (2006). Econometric accounting of the Australian corporate tax rates: A firm panel example. Accounting Research Journal, 19(1), 64-73.

xl. Fernández, R. E. \&Martínez, A. A. (2011). Determinants of effective tax rate: Evidence for USA and the EU. Intertax, $39(8 / 9), 381-395$.

xli. Fernández, R. E. (2004). Los factorescondicionantes de la presión fiscal empresarialespañola a partir de la informacióncontable. Especial mención a lasdecisionesfinancieras. Revista Española de Financiación y Contabilidad, 120, 125-159.

xlii. Foster, B. P., \& Ward, T. J. (2007). The incremental usefulness of income tax allocations in predicting one-yearahead future cash flows. Journal of Applied Business Research, 23 (4). 37-48.

xliii. Ftouhi, K. (2020). International tax planning techniques: A review of the literature. Journal of Applied Accounting Research. 21 (2).

xliv. Ftouhi, K., \&Ghardallou, W. (2019). International tax planning techniques: A review of the literature. Emerald Insight. 329-342. https://www.emerald.com/insight/0967-5426.htm. 
xlv. Goolsbee, A. (1998). Investment tax incentives, prices, and the supply of capital goods. Quarterly Journal of Economics, 113, 121-148.

xlvi. Gordon, R., \& Dietz, M. (2006). Dividends and taxes. A paper presented for the David Bradford Memorial Conference, New York University Law School.

xlvii. Hanlon, D., Navissi, F. \&Soepriyanto, G. (2014). The value relevance of deferred tax attributed to asset revaluations. Journal of Contemporary Accounting and Economics, 14(2), 1-42.

xlviii. Hanlon, M., \&Heitzman, S. (2010). A review of tax research. Journal of Accounting and Economics, 50, $127-178$.

xlix. Hanna, J., \& Shaw, Z. W. (2018). Banks' deferred tax assets during financial crisis. Review of Quantitative Finance and Accounting, 53(2), 52-550.

l. Harris, P., \& Oliver, D. (2010). International Commercial Tax. Cambridge University Press.

li. Heim, B. T., \& Lurie, I. Z. (2010). The effect of recent tax changes on tax-preferred retirement saving behavior. National Tax journal, Research Gate.

lii. House, C., \& Shapiro, M. D. (2006). Temporary investment tax incentives: Theories with evidence from bonus depreciation. National Bureau of Economic Research (NBER).Doi 10. 3386/w12514.

liii. Hussein, A. A., Hassan, M., Rafiq, M., Abdulah, M., \&Qudus, A. (2020). Impact of investment decision and interest rate on firms' financial performance of fuel and energy sector of Pakistan. International Journal of Advanced Science and Technology, 29(4), 1391-1410.

liv. Jappelli, T., \&Pistaferri, L. (2002). Tax incentives and the demand for life insurance: Evidence from Italy. J Public Econ, 87, 1779-1799.

lv. Jehan, S. N. (2001). Interaction of financing \& investment decisions through transition. Economic Journal of Hokkaido University, 30, 47-54.

lvi. Kafkalas S, Kalaitzidakis P, Tzouvelekas V (2014). Tax evasion and public expenditures on tax revenue services in an endogenous growth model. Eur. Econ. Rev. 70, 438-453.

lvii. Kasozi, J. (2013). Evaluating the investment decision-making process for business expansion into Africa: A case study. Corporate Ownership \& Control, 10(3), 464-473.

lviii. Khurana, I. K., \&Mosser, J. W. (2013). Institutional shareholders' investment horizons and tax avoidance. Journal of American Taxation Association, 35(1), 111-134.

lix. Kim, K. (2015). The information role of the increase in bet deferred tax liabilities as measure of firms' tax benefit. Journal of Taxation and Accounting, 16, 101-135.

lx. Kim, J. D., \&Choul, K. M. (2004). Deferred taxes and firm characteristics. Korean Journal of Business Administration. 1239-1309.

lxi. King, S., \&Sheffrin, S. M. (2002). Tax evasion and equity theory: An investigative approach. International Tax and Public Finance, 9(4), 505-521.

lxii. Kliestik, T. and Michalkova, L. (2017). Review of tax shield valuation and its application to emerging markets finance. Financial Management from an Emerging Market Perspective. GurayKucukkocaoglu and SonerGokten, Intech Open, DOI: 10.5772/intechopen.70943

lxiii. Kumar, P., \& Li, D. (2016). Capital investment, innovative capacity, and stock returns, The Journal of Finance, 2059-2094.

lxiv. Kyamyakova, Y. Y. (2014). Comparative characteristics of Russian accounting standard, 18/02, Accounting for income tax and IAS 12- Income taxes. Young Scientist, 4(2), 50-53.

lxv. Laux, R. C. (2013). The association between deferred tax assets and liabilities and future tax payments. The Accounting Review, 88(4), 1357-1383.

lxvi. Legoria, J. \& Sellers, K. F. (2005). The analysis of SFAS No 109's usefulness in predicting future cash flows from a conceptual framework perspective. Research in Accounting Regulation, 18, 143-161.

lxvii. Liu, X. \& Cao, S. (2007). Determinants of corporate effective tax rates. Evidence from Listed companies in China. The Chinese Economy, 40(6), 49- 67.

lxviii. Marie, K. (2011). Deferred tax - The effect of the implementation of NZ IAS 12: Income Taxes.

lxix. Martin, A. (2009). The impact of taxation on investment localization decision in the context of globalization. Analelestinifice ale Universita III, Alexanduru IOAN CUZA DIN IASI Tomul L,6, 133-142.

lxx. Martinez, A. L. \&Vello, A. (2014). Efficient tax planning: An analysis of its relationship with market risk in Brazil. Aust. J. Basic \& Appl. Sci., 8(3), 393-405.

lxxi. Massbown, A. (2009). Thin capitalization rules and entrepreneurial capital structure decisions. BuR -- Business Research Official Open Access Journal of VHB Verband der HochschullehrerfürBetriebswirtschaft e. 2(2), 147-169.

lxxii. McGee, R. W. (2008). A comparative study of indirect taxes in transition economies and the European Union. In R. W. McGEE (Ed.), Taxation and Public Finance in Transition and Developing Economies. Springer Science.

Ixxiii. Mear, K. M. (2011). Deferred tax--the effect of the implementation of NZ IAS 12: Income taxes. A thesis presented in partial fulfilment of the requirements for the degree of Master of Business Studies (Accountancy) at Massey University, Albany, New Zealand.

lxxiv. Memba, F. \&Nyanumba, J. (2013). Causes of financial distress. A survey of Firms funded by Industrial \& Commercial Development Corporation in Kenya. 4(12).

lxxv. Mgammala, M. H., \& Ismail, K. (2015). Corporate tax planning activities: Overview of concepts, theories, restrictions, motivations and approaches. Mediterranean Journal of Social Sciences, 6(6), 350-359.

lxxvi. Mintz, J. M. (1990). Tax holidays and investment. Working Paper, Country Economic Department. 
lxxvii. Monterrey, M. J. \& Sánchez S. A. (2010). Diferencias en agresividad fiscal entre empresasfamiliares y no familiares. Revista Española de Financiación y Contabilidad, 145, 65-98.

lxxviii. Muzurura, J. \&Sikwila, N. (2018). Taxation, private fixed domestic investment behaviour and Zimbabwe's economic growth. America Journal of Humanities and Social Science Research, 2(5), 26-39.

Ixxix. Myles, G. D. (2007). Economic growth and the role of taxation. Report prepared for the OECD, March, 2007.

lxxx. Nar, M. (2020). Tax holiday as an incentive policy tool. Journal of Economics and Public Finance, 6(1), 1-6.

lxxxi. Nathan - MSI Group. (2004). Effectiveness and economic impact of tax incentives in the SADC Region. (Under Contract No. PCE 1-00-980016-00) USAID/RCSA.

lxxxii. Newman, W., Edmore, T., Milondzo, K., \&Ongayi, W. V. (2016). A literature review on the Impact of IAS/IFRS and Regulations on Quality of Financial Reporting. Risk Governance and Control. Financial Markets \& Institutions, 6(4), 102-108. https://doi.org/10.22495/rcgv6i4art13.

lxxxiii. NIPC, (2020). Compendium of investment incentives, investment policies and protections. Nigeria Investment Promotion Commission.

Ixxxiv. Ogundajo, G. O. \&Onakoya, A. B. (2016). Tax planning and financial performance of Nigerian manufacturing companies. International Journal of Advanced Academic Research for Social and Management Sciences, 2(7), 64-79.

lxxxv. Okenwa, O. C., Chinedu, E. F., \&Chidoziem, O. M. (2017). Assessment of deferred tax recognition and measurement under IFRS and Nigeria-SAS: An empirical examination. Asian Journal of Economics, Business and Accounting, 5(1), $1-21$.

lxxxvi. Oloidi, G. A. (2014). Company income tax and investment decisions: A Behavioral Approach. IOSR Journal of Business and Management, 7(5), 11-19.

lxxxvii. Oteng, E. (2019). Financial literacy and investment decisions among traders in the Techiman municipality. Research Journal of Finance and Accounting, 10(6), 50-60.

lxxxviii. Purina, M. (2016). Deferred taxation under IAS 12 in the chosen Czech and Russian Companies. 19th International Conference, Enterprise and Competitive Environment. Procedia, Social and Behavioral Sciences

lxxxix. Raedy, J. S., Seidman, J. K., \& Shackelford, D. A. (2011). Corporate tax reform, deferred taxes and immediate effect on book profits.

xc. Rosenblatt, P., \&Terterov, M. (2006). Turkey: A Business and Investment Review. GMB Publishing Ltd.

xci. Riem, M. (2016). Corporate investment decisions under political uncertainty. ifo Working Paper, No. 221, ifo Institute - Leibniz Institute for Economic Research at the University of Munich, Munich.

xcii. Richardson, G. \&Lanis, R. (2007). Determinants of the variability in corporate effective tax rates and tax reform: Evidence from Australia. Journal of Accounting and Public Policy, 26, 689-704.

xciii. Salaudeen, Y. M. \&Eze, U. C. (2018). Firms' specific determinants of corporate effective tax rate of listed firms in Nigeria. Journal of Accounting and Taxation, 10(2), 19-28.

xciv. Salawu, R.O. \&Adedeji, Z. A. (2017). Corporate governance and tax planning among non-financial quoted companies in Nigeria. Africa Research Review, 11(3), 42-60.

xcv. Saleh, M. (2018). The impact of tangible and intangible assets investment on the value of manufacturing companies listed in Indonesia Stock exchange. Archive of Business Research, 6(10), 402-414.

xcvi. Seetharaman, A., Niranjan, I., Patwa, N., \&Kejriwal, A. (2017). Study of the factors affecting the choice of investment portfolio by individual investors in Singapore. Accounting and Finance Research, 6(3), 153-168.

xcvii. Shieh, W., Ou, J., \& Wang. J. (2014). The impact of anti-thin capitalization rules on capital structure in Taiwan. International Journal of Economics and Finance, 6(11).

xcviii. Sözbilir, H., Kula, V., \&Baykut, E. (2015). A Research on deferred taxes: A case study of BIST listed banks in Turkey. European Journal of Business and Management, 7(2), 1-11.

xcix. Stewart, G. B. (1999). The Quest for Value: The EVA. Management Guide: USA.

c. Stryckova, I. L. (2014). Corporate investment decisions: Empirical evidence from the Czech Republic. Technical University of Liberec, Faculty of Economics, Department of Finance and Accounting, Czech Republic.

ci. Suandy, E. (2003). Perencanaanpajak edisi 2 (revisi). Salemba Empat: Jakarta.

cii. Talpos, I., \&Vancu, I. (2009). Corporate income taxation effects on investment decisions in the European Union. AnnalesUniversitatisApulensis Series Oeconomica, 11(1), 513-518.

ciii. Tax Guide. (2018). Worldwide corporate tax guide. EY's Tax Services.

civ. The Business Year, (2018). Driving investment in Nigeria: Policies and initiatives. Nigeria Executive Guide Review.

cv. Tijjani, B. \& Peter, Z. (2020). Ownership structure and tax planning of listed firms: Evidence from Nigeria. Academic journals.

cvi. Wang, F., Xu, S., Song, J. \&Cullinan, C. P. (2020). Corporate tax avoidance: A literature review and research agenda. Journal of Economic Survey, 34(4), 793-811.

cvii. Wilson, R., (2009). An examination of corporate tax shelter participants. The Accounting Review, 84(3), $969-999$.

cviii. World Development Report. (2004). A better investment climate for everyone. The World Bank and Oxford University Press. 